\title{
Digest of Minutes of General Interest, Association of Research Libraries, Meeting Held in Philadelphia, June I I, I948
}

Increased Cost of Library of Congress Cards

K. D. Metcalf, chairman, Joint Committee on the Increased Cost of Library of Congress Printed Cards, reviewed the activities of the committee since its appointment and reported that up to now no solution of the problem had been found and that the price of L.C. cards would be raised as announced, on July 1. Mr. Metcalf expressed doubt as to how his committee ought now to proceed, but suggested that since important political changes appear to be impending (involving the certainty of important changes of membership in the House of Representatives committee which is responsible for our difficulties), it would be well to delay further action until after the national election in November and then to consider what remedial action might have a chance of meeting with success. There would then be the possibility of trying to induce the new House Committee on Appropriations to change its position regarding card prices; or, if success along this line did not seem promising, we might work for positive legislation stating that card prices should not include the cost of cataloging.

The executive secretary acknowledged that, for reasons which had seemed to him convincing, he had so far not taken steps to set up the "grass roots" committee which had been called for by the second resolution passed by the joint meeting of A.L.A. and A.R.L. in Chicago in January. After a brief discussion it was voted that the executive secretary be advised to implement the second committee when and if he should consider it necessary.

\section{Fulbright Law and Microcopying Abroad}

The executive secretary stated that so far as he knew there had been no important further development in this matter which had been referred to the advisory committee in January. It was reported that Fulbright funds "for general purposes" had now been cleared for use in China, Burma, the Philippines, and Greece. Mr. Clapp expressed the view that the detailed interpretation of the Fulbright law would vary from country to country. He thought the interests of documentary reproduction might still be served, even though Fulbright funds might not be used to buy film or photographic equipment, for the funds could be used to pay for the travel of scholars who would do the work. He felt that the program for microfilming in China looked very promising.

\section{Early Experience with the Farmington Plan}

Paul North Rice presented a report on the early operations of the Farmington plan as seen from the vantage point of the New York Public Library. The principal points were as follows:

For various reasons the flow of Farmington books made a slower start than had been anticipated. As of the end of May a total of 744 books had been received, 584 from France, 81 from Switzerland, and 79 from Sweden. These books had been, or were in process of being, classified and shipped to 37 of the 54 participating libraries. The largest recipients so far had been the University of Illinois and New York Public Library. The University of Minnesota had naturally received the largest share of Swedish books. A cost study to May 31 indicated that payments to dealers had amounted to $\$ 1296.49$ and that other expenses had raised the cost of the first 744 items to $\$ 1636.72$. The quality of the books received had in general been high, though our Farmington selection instructions had not always been understood, and some serials, reissues, documents, theses, and continuations had been received. One library has asked to have separate bills for the different classifica- 
tions received, but it is pointed out that this would not be possible without a considerable increase in costs.

Mr. Metcalf, chairman of the Farmington Plan Committee, then commented that it seemed to him that our foreign agents had been more selective than had been intended and therefore he doubted that our libraries were getting all the books that they ought to receive. He urged librarians to send him copies of their Farmington cards promptly so that an early check might be made to determine what is not being received which should be sent.

There was general agreement that, owing to the slow start which the plan had made, we lacked a sufficient accumulation of experience to warrant sending a representative now (at the end of the first six months) to talk with our Farmington dealers in France, Switzerland, and Sweden and arrange with them to classify and ship the books directly to the receiving libraries. However, it was hoped that we might be ready to send such a representative abroad late this autumn.

A question was raised as to the extension of the Farmington Plan to additional countries. On the advice of Mr. Metcalf it was voted to authorize the committee to extend the plan to include Norway, Denmark, Belgium, the Netherlands, and Mexico. It was also agreed that Italy might be included if our representative, after visiting the country, should feel that conditions were sufficiently stable to warrant such inclusion. No exact date was set for the foregoing proposed extension, but it was presumably hoped that arrangements might be completed in time to have the extensions take effect as of Jan. I, 1949. Mr. Metcalf urged librarians to maintain their subject commitments without change, if possible, as the Farmington plan is extended to additional countries.

The present system of billing books through the New York Public Library, though it must obviously go beyond the six months originally contemplated, is still to be regarded as temporary. As soon as arrangements can be completed for our Farmington dealers to classify the books abroad and ship directly to receiving libraries, billing will also be direct to the said libraries.

The thanks of the association were voted to the New York Public Library for its fine achievement in keeping the handling costs of Farmington books so low.

Acceptance of Books Confiscated from German Libraries

The director of libraries, University of Pennsylvania, stated that he had received under the Library of Congress cooperative acquisitions program a number of books bearing the mark of ownership of certain German libraries. He had found himself unwilling to add these volumes to the University of Pennsylvania collections because it had seemed to him wrong in principle for these books to be seized and brought to this country. Therefore, acting in his capacity as executive secretary of A.R.L., he had appointed a Committee on Confiscated German Books, consisting of Julian P. Boyd, chairman, Ralph E. Ellsworth, and Keyes D. Metcalf.

In the short time at its disposal Mr. Boyd's committee had not been able to reach complete agreement. The brief preliminary statement which Mr. Boyd submitted led to a very animated but indecisive discussion at the end of which the matter was referred back to the committee for further consideration and report at a later meeting.

\section{Joint Committee on Documentation}

Stephen A. McCarthy, the A.R.L. representative on this committee, and chairman, reported that after an extensive investigation the committee had reached the conclusion that there was no active demand that would justify the organization of a bibliographical research service through libraries such as had been proposed, and therefore it was recommended that the proposal be laid aside until such time as a more active demand should appear. The recommendation was accepted and $\mathrm{Mr}$. McCarthy was authorized to withdraw from the committee and let it disband.

\section{Photographic Reproduction of Wartime Peri- odicals}

Charles H. Brown, chairman of the committee on the above, reported that the distribution of periodicals from the Library of Congress mission and from dealers in Leipzig would be completed this summer; that Edwards Brothers of Ann Arbor planned to complete this summer the reproduction of the 
remaining volumes for the war years of the serials which they had started to reproduce; and that in the autumn it was hoped that reproduction could be started of such other serials of Axis and Axis-occupied countries as are listed in the Union List as having twenty or more subscribers (about 450 in number).

Mr. Brown further reported that practically all member libraries had expressed a wish to receive lists of duplicates available at member libraries and that, with two or three exceptions all member libraries had such duplicates for exchange. He undertook to make the lists available as promptly as possible to members.

\section{Oriental Institutes}

Charles H. Brown, chairman of the A.L.A. Committee on the Orient and South Pacific, reported that the whole matter of libraries in the Orient and of oriental collections in this country (usually in connection with oriental institutes attached to one or another of our universities) was of such consequence and presented such problems that it had been proposed that an informal committee be set up to deal with it-perhaps to be called $\mathrm{Na-}$ tional Committee on Oriental Collections in the United States and Abroad. It was proposed to hold a meeting on the subject at Atlantic City on June 14 , and an invitation was extended to all A.R.L. members who were interested to attend.

Warner G. Rice referred to the difficulty and the cost of cataloging oriental materials and expressed the hope that some scheme of centralized cataloging of such materials on a fee basis might be worked out. He indicated that the University of Michigan Library might soon be willing to make the experiment of cataloging Japanese materials for other libraries on such a plan.

\section{Pricing of the Index of Canadian Periodicals}

The Executive Secretary reported that owing to the concerted action which had been taken by the association, the plan to market the Index of Canadian Periodicals on a service basis was almost certainly being given up, though a foreign price might be established for the publication which would be somewhat higher than the domestic.

\section{Documents Expediter}

Homer Halvorson, chairman of the Joint Committee on Government Publications, reported that the project of maintaining a documents expediter in Washington was now drawing to the close of its second year. He stated that as of Apr. I, 1948, I, 400,000 pieces had been distributed and the number of participating libraries had grown to 63 , and he strongly urged that the project be continued. Some doubt was expressed as to its usefulness but it was warmly defended, particularly by the Library of Congress. There was discussion of the financing of the project and the view was expressed that some better system might be devised. It was accordingly voted that the project be continued but that the committee investigate the financial basis on which it is now operated with a view to improvement, if possible, and that it report to the midwinter meeting of the association.

\section{Library Statistics}

Guy R. Lyle, chairman of the Committee on Statistics, stated that his committee had reached a preliminary conclusion that if it should recommend some new method of counting holdings (say by bibliographical unit), this would imply a necessity for libraries to recount their existing holdings, and he felt that many would be unwilling to undertake the labor of doing so except upon some simplified approximate systems such as measuring the number of linear feet of shelved material and multiplying by some agreed number. $\mathrm{He}$, therefore, raised a question as to whether members would approve in principle some such system. In the discussion that followed, opinion appeared to be divided; but it was voted to authorize the committee to devise and recommend some simplified method of recounting book stocks and to report back to a later meeting.

\section{Committee on Microfilming Cooperation}

Mr. Tate, chairman, reported that a center of information on long-run microfilming projects, as previously contemplated, had been established at the Library of Congress, and that a "Preliminary Draft of Standards for the Microphotographic Reproduction of Newspapers" had been prepared for the committee by Herman H. Fussler and Cabot T. 
Stein. However, the list of newspapers available on microfilm which he had hoped to have issued by A.R.L. by the time of the present meeting had been delayed by the absence of Mr. Schwegmann from the Library of Congress on a mission to Europe. There might be a short further delay but Mr. Tate was very hopeful that the list could be got out in the near future. It will run to perhaps 300 mimeographed pages.

\section{Third Edition of the Union List of Serials}

The executive secretary presented on behalf of Andrew D. Osborn, A.R.L. representative on the Joint Committee on the Union List of Serials, a brief report in which it was stated that on account of the problem of costs the joint committee had agreed to plan for a third edition of the Union List, not immediately, but in from seven to ten years time. Meanwhile, the chairman of the joint committee had been authorized to seek foundation and business support, especially in the form of endowment. Should an adequate endowment be secured, a permanent editorial office would be set up. The joint committee has also agreed that it is ready to take over the work of the A.L.A. committee which was concerned with a new supplement to the union list, though it was decided that this supplement also is not to be pushed in the immediate future.

Anonymous and Pseudonymous Cards in the Supplement to the Library of Congress Catalog of Printed Cards

Frederick H. Wagman, director, Processing Department, Library of Congress, reported that approval had been given by the Library of Congress of the inclusion of anonymous and pseudonymous cards in the Supplement to the Catalog of Books Represented by Library of Congress Printed Cards.

\section{Committee on Research Libraries and the Library of Congress}

The executive secretary reported that the Librarian of Congress had referred to the association for consideration a number of important problems which concern both the $\mathrm{Li}$ brary of Congress and the other research libraries of the country. A preliminary list of such problems is as follows: ( 1 ) the bases on which the Library of Congress would make full sets of printed cards available without charge to United States libraries, (2) the problem of federal subsidy to selected libraries giving extensive service to federal field offices and the allied problem of regional federal libraries, (3) cooperative cataloging arrangements, (4) the problem of including catalog cards, other than Library of Congress printed cards, in the Cumulative Catalog, (5) interchange of personnel on a swapping basis for periods of a year or so between the Library of Congress and other libraries; and (6) the role of the Library of Congress as an informational clearing house in relation to matters not now covered.

To deal with these and similar problems a committee on research libraries and the Library of Congress has been appointed with the following membership: Donald Coney, Keyes D. Metcalf, Charles W. David, chairman, and the Librarian of Congress has designated Frederick $H$. Wagman to be adviser to the committee. In order to get much of its preliminary work done promptly the committee has assigned to each of the above mentioned problems a subcommittee of lone, but there has not yet been time for reports to be received and decisive progress to be made, but it is hoped that matters of real significance can be reported to the next meeting of the association.

\section{United States Book Exchange, Inc.}

It was reported that the advisory committee has authorized acceptance of membership in the United States Book Exchange, Inc., which is being set up as a successor agency to the American Book Center for War-Devastated Libraries, Inc. The new agency has already been incorporated in the District of Columbia under a temporary board of directors and temporary by-laws. The organization is to be completed at a meeting to be held at the Library of Congress on June 24. Mr. Clapp expressed optimism concerning the future of the new organization.

\section{Exchanges with Russia}

The executive secretary reported the receipt, through the courtesy of the University of Michigan L:brary, of a copy of a letter from Melville J. Ruggles, cultural attaché (Continued on page 354) 


\section{Research and Publications}

It has been indicated that in the field of research and publications the task of the executive secretary should be to encourage, suggest, and stimulate. I have endeavored to become better acquainted with the problems and needs in general, and at the suggestion of the board of directors am compiling a list of research studies now under way at the various library schools. Throughout the year I have made an effort to discover individuals with particular fields of interest and encourage their continued activity with a view to publication. It has been possible to talk with several persons on different subjects, and I know that in at least a few cases some specific results have been achieved. I am in a position to learn about a good many news items which I pass on to College and Research Libraries as well as other professional journals, and I have assisted A. L. Remley in securing advertising. A "Newsletter" to all the members went out in December.

\section{A.L.A. Relationships}

Perhaps before closing I should say a word or two about relationships with A.L.A. I have found everyone at Headquarters most cordial and cooperative. It is understood that I am responsible directly to my board of directors. I meet with the heads of the departments at their weekly meetings, at which times there is the specific opportunity to present the needs and interests of A.C.R.L., and at all times there is a free exchange of ideas, advice, and counsel.

\section{Digest of Minutes}

\section{(Continued from page 350)}

at the American Embassy in Moscow, which indicated that endeavors by the embassy to facilitate exchanges between American and Russian institutions by acting as intermediary had been terminated by the Soviet decree prohibiting direct communication between officials of Soviet institutions and representatives of foreign governments in the Soviet Union and specifying that such communications must be channeled through the Ministry of Foreign Affairs. Mr. Ruggles expressed the view that it would be unwise for American institutions to continue sending publications on exchange or to enter upon a barter arrangement without concrete evidence of reciprocity.

\section{Cumulative Book Index}

Lawrence Heyl of the Princeton Library reported that the $\mathrm{H}$. W. Wilson Company proposed to discontinue the present full coverage of books in English in the Cumulative Book Index and that it was to become a cata- $\log$ of books printed in this country only. This change was being made, following one of the Wilson questionnaires, in the interest of keeping the Index at its present price instead of keeping the present coverage and raising the price 25 to 30 per cent. Mr. Heyl felt that this was a great mistake-that the Index in its present form would save libraries in labor far more than they would suffer through the increased cost-and he therefore urged the association to take a stand against the proposed reduced coverage. After a brief discussion it was voted unanimously that the association urge the Wilson Company to continue the C.B.I. in its present form.

\section{Date of the Next Meeting}

After a brief discussion it was voted to hold the next meeting in Chicago at the time of the A.L.A. Midwinter Conference.

Charles W. David Executive Secretary 